\title{
Pseudopeptide Amyloid Aggregation Inhibitors: In Silico, Single Molecule and Cell Viability Studies
}

\author{
Morgan Robinson 1,2 (D), Jennifer Lou ${ }^{3}$, Banafsheh Mehrazma ${ }^{4}$, Arvi Rauk ${ }^{4}$, Michael Beazely ${ }^{2, *(D)}$ and \\ Zoya Leonenko ${ }^{1,3, *}$ \\ Department of Biology, University of Waterloo, Waterloo, ON N2L 3G1, Canada; m9robinson@uwaterloo.ca \\ School of Pharmacy, University of Waterloo, Waterloo, ON N2L 3G1, Canada \\ Department of Physics and Astronomy, University of Waterloo, Waterloo, ON N2L 3G1, Canada; \\ jenniferwulou@gmail.com \\ 4 Department of Chemistry, University of Calgary, Calgary, AB T2N 1N4, Canada; \\ bmehrazm@ucalgary.ca (B.M.); rauk@ucalgary.ca (A.R.) \\ * Correspondence: mbeazely@uwaterloo.ca (M.B.); zleonenk@uwaterloo.ca (Z.L.)
}

check for updates

Citation: Robinson, M.; Lou, J.; Mehrazma, B.; Rauk, A.; Beazely, M.; Leonenko, Z. Pseudopeptide Amyloid Aggregation Inhibitors: In Silico, Single Molecule and Cell Viability Studies. Int. J. Mol. Sci. 2021, 22, 1051. https://doi.org/10.3390/ ijms22031051

Academic Editor: Grazia Chiellini

Received: 8 December 2020

Accepted: 19 January 2021

Published: 21 January 2021

Publisher's Note: MDPI stays neutral with regard to jurisdictional claims in published maps and institutional affiliations.

Copyright: (C) 2021 by the authors Licensee MDPI, Basel, Switzerland. This article is an open access article distributed under the terms and conditions of the Creative Commons Attribution (CC BY) license (https:// creativecommons.org/licenses/by/ $4.0 /)$.

\begin{abstract}
Neurodegeneration in Alzheimer's disease (AD) is defined by pathology featuring amyloid- $\beta$ $(A \beta)$ deposition in the brain. $A \beta$ monomers themselves are generally considered to be nontoxic, but misfold into $\beta$-sheets and aggregate to form neurotoxic oligomers. One suggested strategy to treat $\mathrm{AD}$ is to prevent the formation of toxic oligomers. The SG inhibitors are a class of pseudopeptides designed and optimized using molecular dynamics (MD) simulations for affinity to $A \beta$ and experimentally validated for their ability to inhibit amyloid-amyloid binding using single molecule force spectroscopy (SMFS). In this work, we provide a review of our previous MD and SMFS studies of these inhibitors and present new cell viability studies that demonstrate their neuroprotective effects against $A \beta(1-42)$ oligomers using mouse hippocampal-derived HT22 cells. Two of the tested SG inhibitors, predicted to bind $A \beta$ in anti-parallel orientation, demonstrated neuroprotection against $\mathrm{A} \beta(1-42)$. A third inhibitor, predicted to bind parallel to $A \beta$, was not neuroprotective. Myristoylation of SG inhibitors, intended to enhance delivery across the blood-brain barrier (BBB), resulted in cytotoxicity. This is the first use of HT22 cells for the study of peptide aggregation inhibitors. Overall, this work will inform the future development of peptide aggregation inhibitors against $\mathrm{A} \beta$ toxicity.
\end{abstract}

Keywords: Alzheimer's disease; amyloid- $\beta$; aggregation inhibitors; neuroprotection; HT22 cells; molecular dynamics; atomic force microscope

\section{Introduction \\ 1.1. Amyloid- $\beta$ Cascade as A Target for Alzheimer's Disease Treatment}

Alzheimer's disease (AD) is a neurodegenerative disease characterized by the accumulation of toxic, misfolded, and aggregated amyloid- $\beta(\mathrm{A} \beta)$. The $\mathrm{A} \beta$ monomer is a 39 to 43 residue peptide fragment produced endogenously within neurons from the cleavage of the transmembrane amyloid precursor protein (APP) by two secretase complexes: $\beta$ and $\gamma$-secretase [1]. An imbalance between $A \beta$ production and clearance in brains of individuals with AD results in increased levels of toxic aggregates [2,3]. It is now widely recognized that soluble $A \beta$ oligomers exhibit the greatest neurotoxicity as compared to the monomer and fibril states of the protein [4-6]. Thus, preventing oligomerization may be a viable strategy for mitigating $\mathrm{A} \beta$ toxicity in $\mathrm{AD}[7]$.

Peptide-based $A \beta$ aggregation inhibitors are potential preventative strategies that have some advantages as compared to monoclonal antibodies (mAbs), including low immunological profile, small size, and tunable, drug-like characteristics. To date, anti$\mathrm{A} \beta$ monoclonal antibodies (mAbs) have been the focus of clinical trials that target $\mathrm{A} \beta$ pathology in AD. Unfortunately, these clinical trials have not lived up to the expectations 
suggested by preclinical studies in $\mathrm{AD}$ animal models, leading many to doubt the prevailing amyloid cascade hypothesis [8-10]. Early clinical evidence suggested that the $\mathrm{mAb}$, Solanezumab, may change disease trajectory when administered early or in pre-clinical AD stages, but unfortunately, phase 3 trials were not successful [11,12]. Other antibodies such as aducanumab have demonstrated the ability to reduce $A \beta$ deposition in early and pre-AD patients [13], however the effects on cognitive decline in $\mathrm{AD}$ patients are less clear.

Peptide $A \beta$ aggregation inhibitors have been shown to reduce $A \beta$ aggregation kinetics and modify the structure of $A \beta$ aggregates prepared in vitro by preventing fibrillization [14-21]. Several of these $A \beta$ peptide inhibitors have demonstrated positive anti-neurotoxic effects against $A \beta$ in vitro; in addition, reductions in pathological markers, including $\mathrm{A} \beta$ deposition, fibrillogenesis and oxidative stress, as well as improvements in memory, have been observed in vivo $[14,17,22-26]$. The potential of $A \beta$ targeted therapeutics as a preventative measure against $\mathrm{AD}$ will only increase as early detection of $\mathrm{AD}$ is realized [27]. The SG inhibitors studied in this report have been developed using a rational drug design approach (shown in Figure 1), beginning with a molecular dynamics (MD) simulation screen, followed by single molecule biophysics experimental validation. In this report, we build on these studies with in vitro cell viability assays to further validate their neuroprotective role in HT22 cells. These new compounds, in conjunction with other $A \beta$ targeted drugs such as mAbs, may be the way forward to prevent neurodegeneration caused by $\mathrm{A} \beta$ in $\mathrm{AD}$.

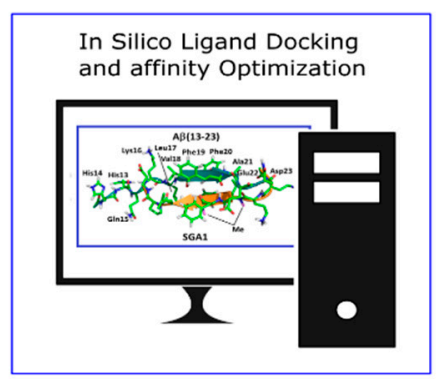

Lead Candidates Chosen

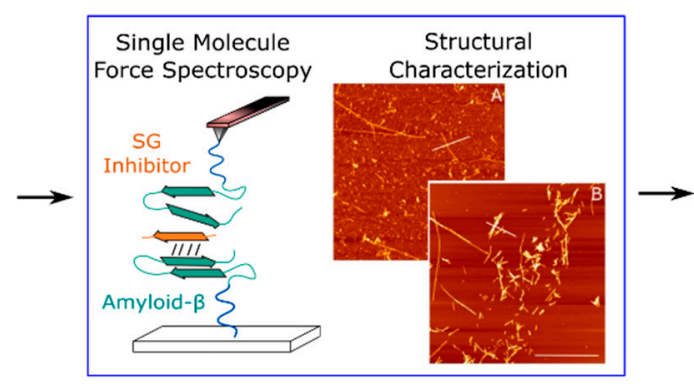

Target Engagement Verification

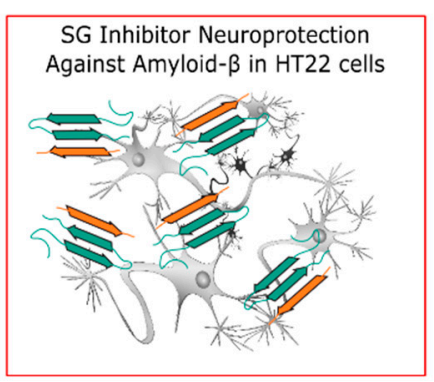

Physiological Screening

Figure 1. Drug Development Pipeline. In the first part, A $\beta$ in silico screening of an SG inhibitor library is performed, wherein the inhibitors with optimal binding affinities were selected for further characterization. Select inhibitors chosen from affinity optimization were screened in single molecule force spectroscopy (SMFS) studies to verify target engagement and ability to reduce $A \beta-A \beta$ binding (blue, these studies were previously reported). Inhibitors were then screened for toxicity and neuroprotection against $A \beta$, results presented for the first time in this article (orange).

\subsection{SG Inhibitor Design Rationale}

The synthetic pseudo-peptide inhibitors, designated SG, were designed and screened in silico by Dr. Arvi Rauk's group using a computer aided drug design approach. The inhibitors, designated as SGA, SGB, SGC, or SGD, were designed to bind to the aggregationprone region of $A \beta, A \beta(16-23)$ or KLVFFAED, with high specificity and high affinity [28-34]. The peptide motif was selected as this region has been shown to have the high affinity and specificity for full length $A \beta[14,15,20]$. By binding as a $\beta$-sheet, the peptide can interfere with the aggregation of $A \beta$ into neurotoxic oligomers. Propagation is inhibited by the placement of methyl groups on one side of the peptide backbone. The peptide is limited to eight residues to avoid it eliciting an immune response [32-34]. The peptide terminates in charged residues complementary to K16, E22, and D23 of A $\beta$, to improve binding affinity and direct the SG-A $\beta$ complex into antiparallel (SGA, SGB) or parallel (SGC, SGD) $\beta$ sheets. Unnatural amino acid residues are incorporated to improve resistance to enzymatic degradation. These include D-residues (SGB, SGD) as well as L-residues (SGA, SGC). Selection of the specific residues was made on the basis of sophisticated docking using molecular operating environment (MOE), and the affinities assessed by MD simulations 
and umbrella sampling. Recognizing that BBB penetration may be a problem, SG inhibitors were myristoylated in the hope that it may be recognized by a fatty acid transporter in the BBB.

Previous MD simulations predicted that SG inhibitors have a rigid backbone that orients with the $\mathrm{N}$-methyl groups on the outer face of the SG-A $\beta$ complex $[28,30,31,33]$, Figure 2 shows the most probable predicted binding of an SG inhibitor with $A \beta(13-23)$, which is designed to bind $A \beta$ in antiparallel orientation. The $N$-methyl groups on the outer face are hypothesized to prevent the growth of $\beta$-sheet oligomers by blocking inter- and intra-molecular hydrogen bonding of $\mathrm{A} \beta$ peptides. In addition, $\mathrm{MD}$ simulations predict that SG inhibitors can have edge and site specificity to $A \beta$ [31]. Since both faces of the A $\beta$ peptide are available for aggregation effectively, inhibiting both the top and bottom faces would be important to completely inhibit aggregation. It is important to note that a high homodimer stability of the SG inhibitors would lower the effective net binding affinity to $A \beta$ and needs to be considered for optimal target engagement [30]. Table 1 shows the previously calculated homodimer dissociation energy $\left(\Delta \mathrm{G}_{\text {dimer }}\right)$ and the average effective dissociation energy $\left(\Delta \mathrm{G}_{\mathrm{eff}}\right)$ of several SG inhibitors tested in this paper. Moreover, $\Delta \mathrm{G}_{\text {eff }}$ considers homodimer stability $\left(\Delta \mathrm{G}_{\text {dimer }}\right)$ and the average dissociation energy between the top and bottom face of $A \beta$. A negative $\Delta G_{\text {eff }}$ implies that SG-A $\beta$ complexes are more stable than $A \beta-A \beta$ complexes, for more information on how these values were calculated see [30]. Table 2 lists the amino acid sequences for the SG inhibitors studied in this report.

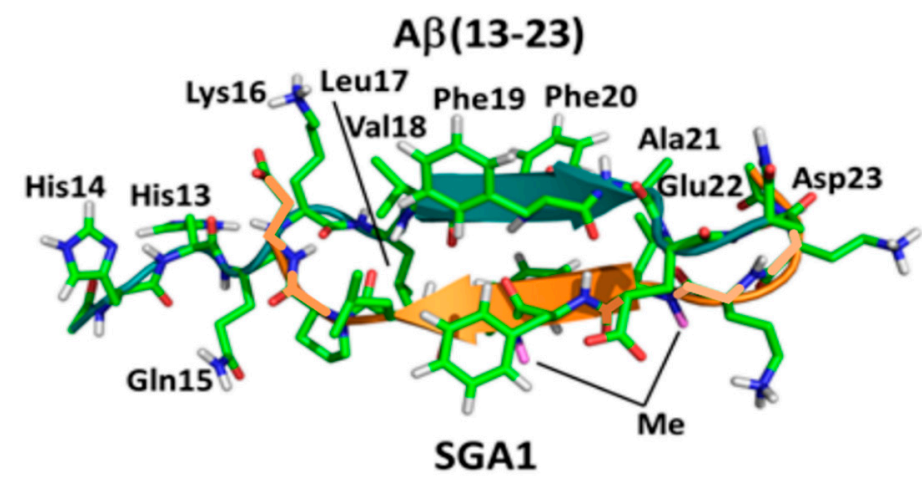

Figure 2. SG-A $\beta(13-23)$ complex. $A \beta$ backbone is shown in green, SGA1 is shown in orange. $\mathrm{N}$-methylated peptide backbone (Me) appears on the bottom face of the complex.

Table 1. SG Inhibitor classes and predicted binding characteristics of select SG inhibitors tested in this report. SGA and SGC inhibitors were tested in this report.

\begin{tabular}{|c|c|c|}
\hline SG Inhibitor Classes & Anti-Parallel & Parallel \\
\hline L-enantiomer & SGA & SGC \\
\hline D-enantiomer & SGB & SGD \\
\hline SG Inhibitor Binding & $\Delta \mathrm{G}_{\text {dimer }}(\mathrm{kJ} / \mathrm{mol})$ & Average $\Delta G_{\text {eff }}(\mathrm{kJ} / \mathrm{mol})$ \\
\hline SGA1 & 21 & 3 \\
\hline SGA3 & 46 & -4 \\
\hline SGC1 & 26 & -24 \\
\hline Myr-SGA1 & 62 & 6 \\
\hline
\end{tabular}

The substitution of proline residues to the basic SG inhibitor templates may disrupt $\beta$-sheet interactions, prevent aggregation, and even disassemble preformed $A \beta$ fibrils $[20,22,35]$. Further modifications can improve peptide properties, for example: terminal charged amino acid residues can increase solubility [17]; synthetic, N-methylated and D-amino acid residues can improve both proteolytic stability and target engagement $[16,19,25,34-36]$; and the addition of shuttle peptides and hydrophobic residues could improve the blood-brain barrier (BBB) permeation [24,35]. There are major challenges 
associated with drug delivery to the brain; most importantly, the restriction presented by the BBB, which is known to exclude all but $2 \%$ of drugs [37]. The N-methyl backbone of the SG inhibitors may improve cell membrane translocation and BBB permeability by reducing the backbone electrostatic contributions and increasing the hydrophobicity of the peptide. To further improve BBB uptake as well as to increase localization near the membrane, the major site of $A \beta$ aggregation, SG inhibitors with a myristic acid tail on the $\mathrm{N}$-terminus have been proposed [33,38,39].

Table 2. The sequences of SG inhibitor pseudo-peptides. Legend: $\beta$-alanine (Bala), $\mathrm{N}$-methylated backbone residue (Me), diaminobutyric acid (Daba), ornithine (Orn), and myristic acid tail (Myr).

\begin{tabular}{cc}
\hline SG Inhibitor & Inhibitor Sequence \\
\hline SGA1 & Daba-Orn-(Me)Leu-Phe-(Me)Phe-Leu-Pro-Bala \\
MyrSGA1 & Myr-Daba-Orn-(Me)Leu-Phe-(Me)Phe-Leu-Pro-Bala \\
SGA3 & Daba-Orn-(Me)Leu-Phe-(Me)Phe-Leu-Ala-Glu \\
MyrSGA3 & Myr-Daba-Orn-(Me)Leu-Phe-(Me)Phe-Leu-Ala-Glu \\
SGC1 & Glu-Ala-(Me)Phe-Phe-(Me)Phe-Leu-Orn-Daba \\
\hline
\end{tabular}

\subsection{Target Verification by Single Molecule Force Spectroscopy}

In Leonenko's group, we previously demonstrated that these SG inhibitors effectively prevented $A \beta$ dimerization using a single-molecule force spectroscopy (SMFS) biosensor approach (Figure 3) [21,30,40,41]. In a proof-of-concept study, we showed that SGA1 decreases the number $A \beta$ binding events in a concentration dependent manner with increased effectiveness at higher concentration [21]. Later, the effects of other inhibitors (SGA3, SGC1 and Myr-SGA1) were compared, and it was confirmed that they all reduced the binding probability of $A \beta$, although no significant difference between inhibitors was found [30]. In further analysis of the unbinding force distribution, we found that inhibitors shifted the A $\beta$ binding probability distribution in unique ways. SGC1 increased the binding probability at higher force, Myr-SG1 decreased the binding probability at higher force, and SGA3 more uniformly reduced binding probability across the unbinding force distribution, shown in Figure 3 below [30]. This may suggest that the SG inhibitors have different likelihoods of blocking different binding configurations of $A \beta$; for instance, they may preferentially block parallel/anti-parallel binding orientations, or may block different types of intermolecular forces, such as hydrophobic interactions, electrostatic or hydrogen bonding [30].

\subsection{Structural Characterization of SG-A $\beta$ Aggregation}

Experimental validation of the effect of SGA1 on amyloid aggregation and structure was performed previously by several methods: including ThT fluorescence, circular dichroism (CD), Western blot and AFM imaging. The influence of SGA1 on A $\beta(1-40)$ and $A \beta(1-42)$ aggregation by ThT fluorescence assay was performed at a concentration of $25 \mu \mathrm{M} \mathrm{A} \beta(1-40)$ and $\mathrm{A} \beta(1-42)$ at $37^{\circ} \mathrm{C}$ for 5 to 7 days, across a broad range of SG inhibitor concentration to determine the $\mathrm{IC}_{50}$ inhibitory ligand:A $\beta$ ratio [33]. For SGA1, the $\mathrm{IC}_{50}$ ligand:A $\beta(1-40)$ ratio occurred at 0.2 , while the control, $\mathrm{N}$-methylated KLVFF peptide (Ac-K(me)LV(me)FF-NH2), was approximately 2.0 [33]. The $\mathrm{IC}_{50}$ inhibitory ligand/A $\beta 1-42$ ratio was approximately double for SGA1 of 0.5 compared to the control N-methylated KLVFF peptide 4.0 [33]. The results from ThT fluoresence assay are further supported by Western blot analysis, which demonstrated similar stoichiometric molar ratios of SG inhibitor to $A \beta(1-42)$ resulted in the complete inhibition of higher molecular weight oligomers and reduction in dimers and trimers in a concentration-dependent manner [33]. 


\section{Single Molecule Force Spectroscopy}

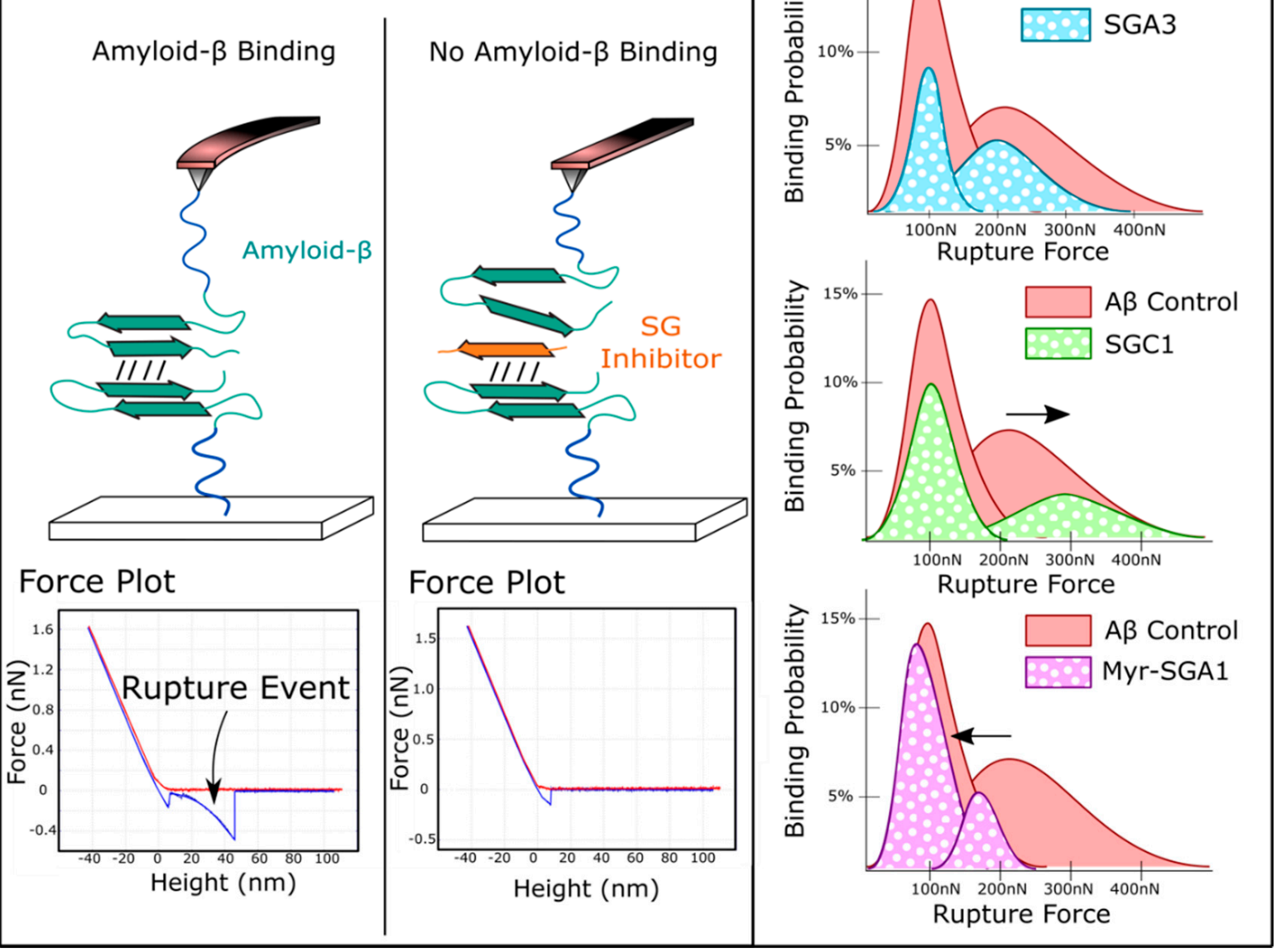

Figure 3. Illustration of previous. Single Molecule Force Spectroscopy experiments that showed A $\beta(1-42)-A \beta(1-42)$ unbinding forces are modified by SG inhibitors. This suggests inhibitors block $A \beta(1-42)-A \beta(1-42)$ binding orientations in unique fashion, results previously published in Mehrazma et al. 2017.

AFM imaging studies of $A \beta$ aggregation were carried out independently by the Leonenko lab that demonstrates the anti-aggregation properties of the SGA1 inhibitor [21]. In Hane et al., solutions of $A \beta(1-42)$ (prepared by the Fezoui method) with and without SGA1 were deposited onto freshly cleaved mica at 1:1 ratio with a final concetration of $110 \mu \mathrm{M} A \beta(1-42)$, and then incubated for 1,6 and $24 \mathrm{~h}$, before being washed, dried and than imaged by AFM (Figure 4, adapted with permission) [21]. Fibril length of $A \beta(1-42)$ aggregates was greatly reduced in the presence of the SG inhibitor compared to the $A \beta$-only control [21]. In addition, the amount of fibrils and oligomers were quantified across the time points, showing that SG inhibitor decreased the amount of $A \beta(1-42)$ fibrils compared to oligomers [21]. In paying closer attention to the $1 \mathrm{~h}$ timepoint, the surface roughness of the background for $A \beta(1-42)$ without inhibitor suggesting that there is a higher degree of absorption of the amyloid aggregates on the surface compared to $A \beta(1-42)$ in the presence of SG inhibitors. At $1 \mathrm{~h}$, when SG inhibitor is present, mica background can be seen below the amyloid aggregates, while for the $A \beta(1-42)$ control, it appears as though a thicker layer of smaller aggregates is present [21]. This may suggest that the SG inibitor when complexed with $A \beta$ may block the ability of $A \beta(1-42)$ aggregates from absorbing onto the surface of the mica by preventing hydrogen bonding between $A \beta(1-42)$ and the mica surface, and are thus more easily washed away during sample preparation. 
$1 \mathrm{~h}$

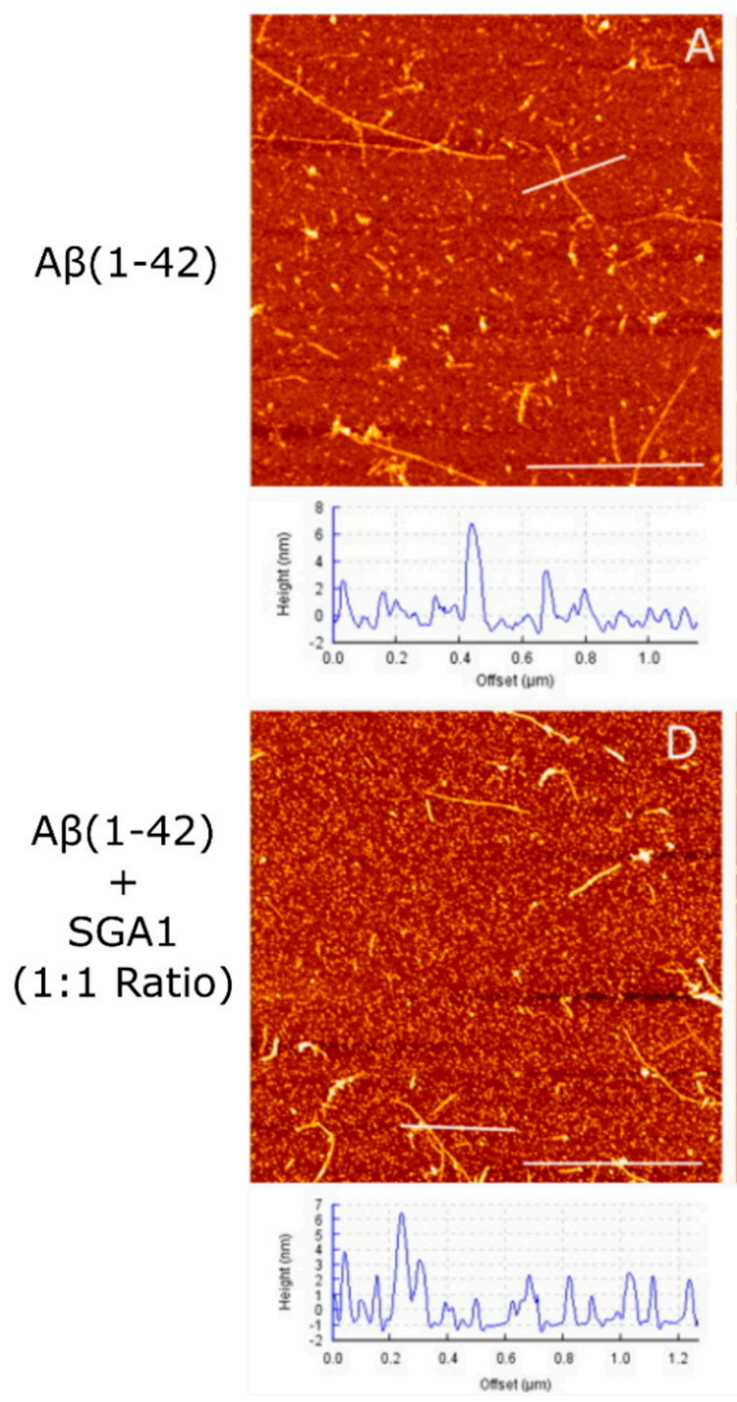

$6 \mathrm{~h}$
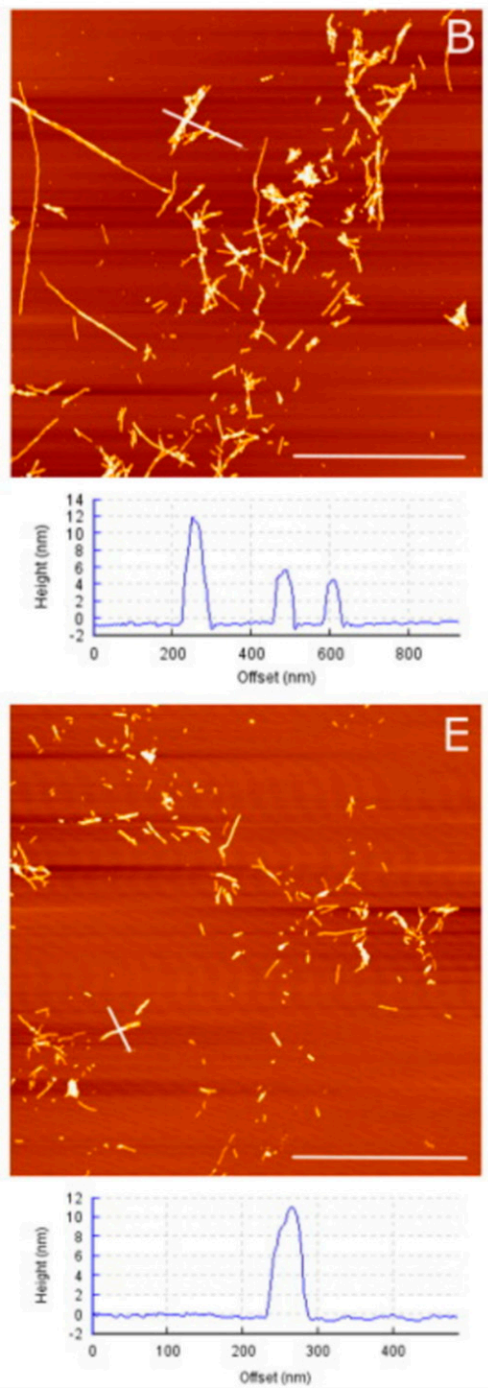

$24 \mathrm{~h}$
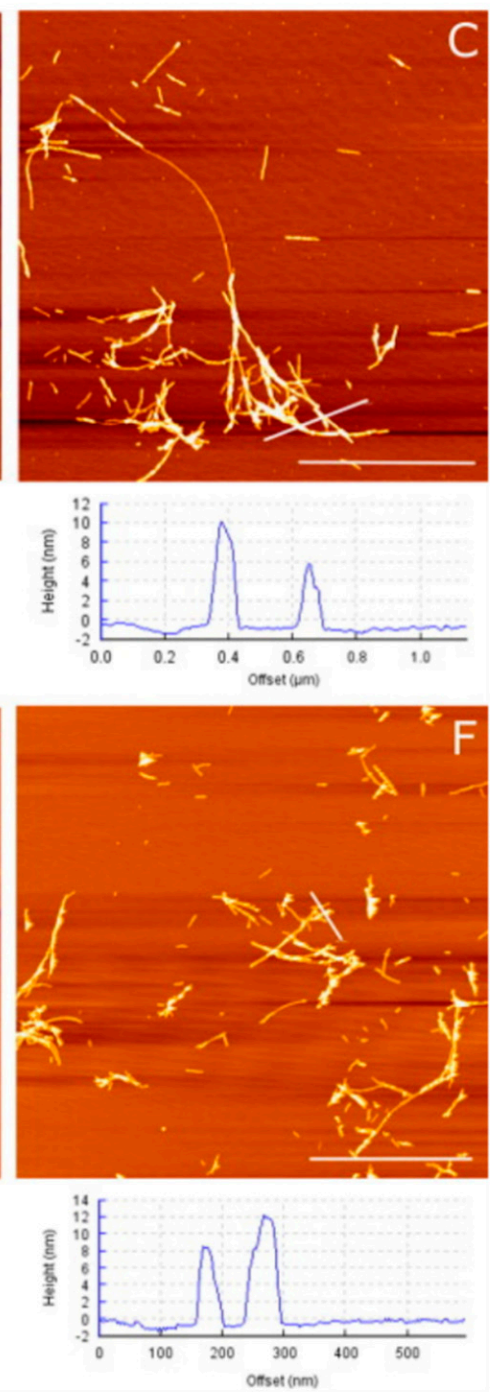

Figure 4. AFM images of $A \beta(1-42)$ with and without SGA1 on freshly cleaved mica. Control A $\beta(1-42)$ at $110 \mu \mathrm{M}$ after (A) $1 \mathrm{~h},($ B) $6 \mathrm{~h}$, and (C) $24 \mathrm{~h}$ and with equimolar concentration of SGA1 after (D) $1 \mathrm{~h},(\mathrm{E}) 6 \mathrm{~h}$ and (F) $24 \mathrm{~h}$, adapted with permission from Hane et al., Biosensors and Bioelectronics; published by Elsevier, 2013. [21].

\subsection{Cell Viability Studies.}

In this report, we extend our previous computational and biophysical studies to test five SG inhibitors in cell viability studies, which were done in the Beazely laboratory. The five inhibitors are shown below in Figure 5. We demonstrate that two of the SG inhibitors, SGA1 and SGA3, improve the cell viability of the mouse neuronal cell line HT22 in $A \beta$ rescue experiments compared to $A \beta(1-42)$ oligomers alone. We also discovered that both myristoylated inhibitors were intrinsically toxic to cells and further potentiated the toxicity of $A \beta$ oligomers. We compare these cell viability studies in the discussion section to previous biophysical studies and synthesize our knowledge learned across the three different methodological approaches: molecular dynamics simulations, single molecule biophysical studies, and in vitro cell viability assays. 

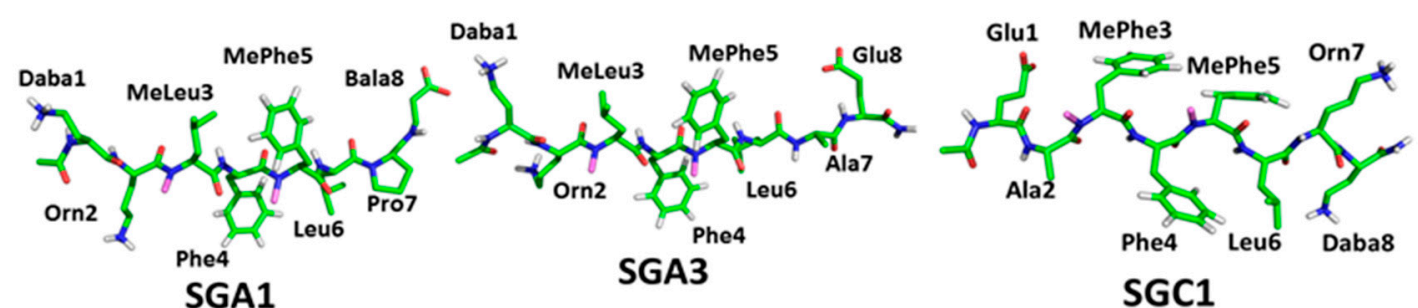

SGC1
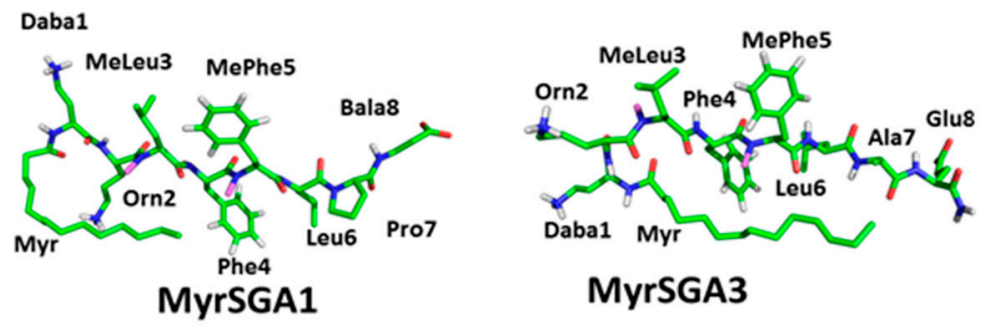

Figure 5. Structure of SG inhibitors tested in the drug toxicity and $A \beta(1-42)$ rescue experiments presented in this report.

\section{Results}

\subsection{SG Inhibitor Toxicity}

Before evaluating the potential protective effects of the compounds against $A \beta(1-$ 42) toxicity, we determined whether these compounds exhibited any toxicity in vitro (Figure 6). We found that SG inhibitors are largely non-toxic up to $10 \mu \mathrm{M}$, except for the myristic acid-modified compounds. Myristic acid-modified inhibitors demonstrated a dose-dependent toxicity for both Myr-SGA1 and Myr-SGA3, with significant reductions in HT22 cell viability at 5 and $10 \mu \mathrm{M}$. The $\mathrm{IC}_{50}$ for the toxicity of the Myr-SGA1 and Myr-SGA3 were both approximately $7.5 \mu \mathrm{M}$, whereas for standard inhibitors, no significant reduction in cell viability was observed over the range of concentrations tested here, therefore IC50 could not be calculated for SGA1, SGA3 and SGC1.

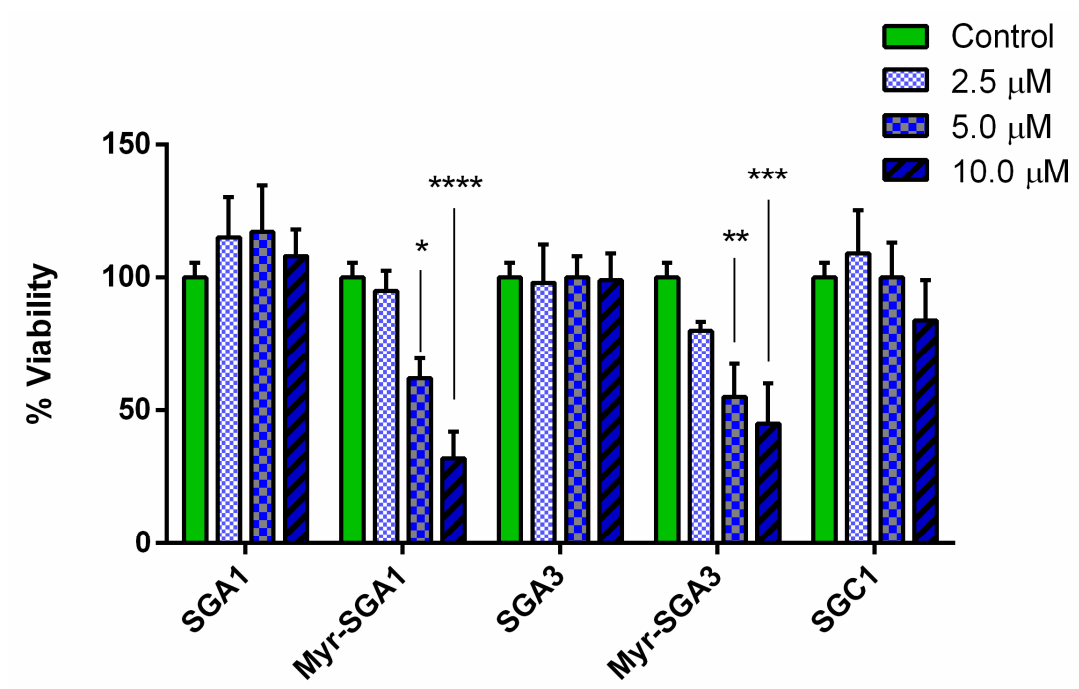

Figure 6. HT22 cells treated with SG inhibitors for $24 \mathrm{~h}$. Cell viability was assessed by MTT assay and expressed as a percentage of untreated control, error bars represent SEM, $n=4$ for each concentration and inhibitor, ${ }^{*} p<0.05,{ }^{* *} p<0.01^{* * *} p<0.005$, and ${ }^{* * * *} p<0.001$, one-way ANOVA $(\alpha=0.05)$ with Dunnett's multiple comparison test was performed to assess statistical significance.

\subsection{The Effects of SG Inhibitors on A $\beta$ Oligomer Toxicity}

The protective effects of SG inhibitors on $A \beta(1-42)$ oligomer toxicity, as assessed in the HT22 cell model, were small but promising (Figure 7A) when considering the protective 
effects from $A \beta(1-42)$ observed in similar studies in HT22 cells [42]. A $\beta(1-42)$ oligomers $(5 \mu \mathrm{M})$ caused a reduction in viability to $50 \pm 5 \%$ of true control; this is in line with other in vitro assays in SHSY5Y cells and HT22 cells which typically observe between $50-60 \%$ reduction in cell viability at this concentration $[42,43]$. Two inhibitors (SGA1* and SGA3 ${ }^{* *}$ ) improved the cell viability of HT22 cells to $65 \pm 6 \%$ and $68 \pm 3 \%$ at twice the molar concentration of A $\beta\left(p<0.05^{*}\right.$ and $p<0.01^{* *}$, respectively), meanwhile SGA3 caused an improvement in cell viability at equimolar concentration of $\mathrm{A} \beta\left(p<0.05^{*}\right)$ to $64 \pm 3 \%$ of true control. SGC1 showed no statistically significant effect on $A \beta(1-42)$ toxicity at the range of concentrations tested here. The toxicity of Myr-SGA1 and Myr-SGA3 inhibitors appeared to compound with that of $A \beta(1-42)$, reducing cell viability to below $30 \%$ (Figure $7 \mathrm{~B}$ ). There was a trend toward increased toxicity at low concentration, though compared to $A \beta(1-42)$ treated control the effect was not statistically significant. DMSO used as vehicle (at $0.1 \%$ ) also caused small reduction in HT22 cell viability, but was also not statistically significant (data not shown).
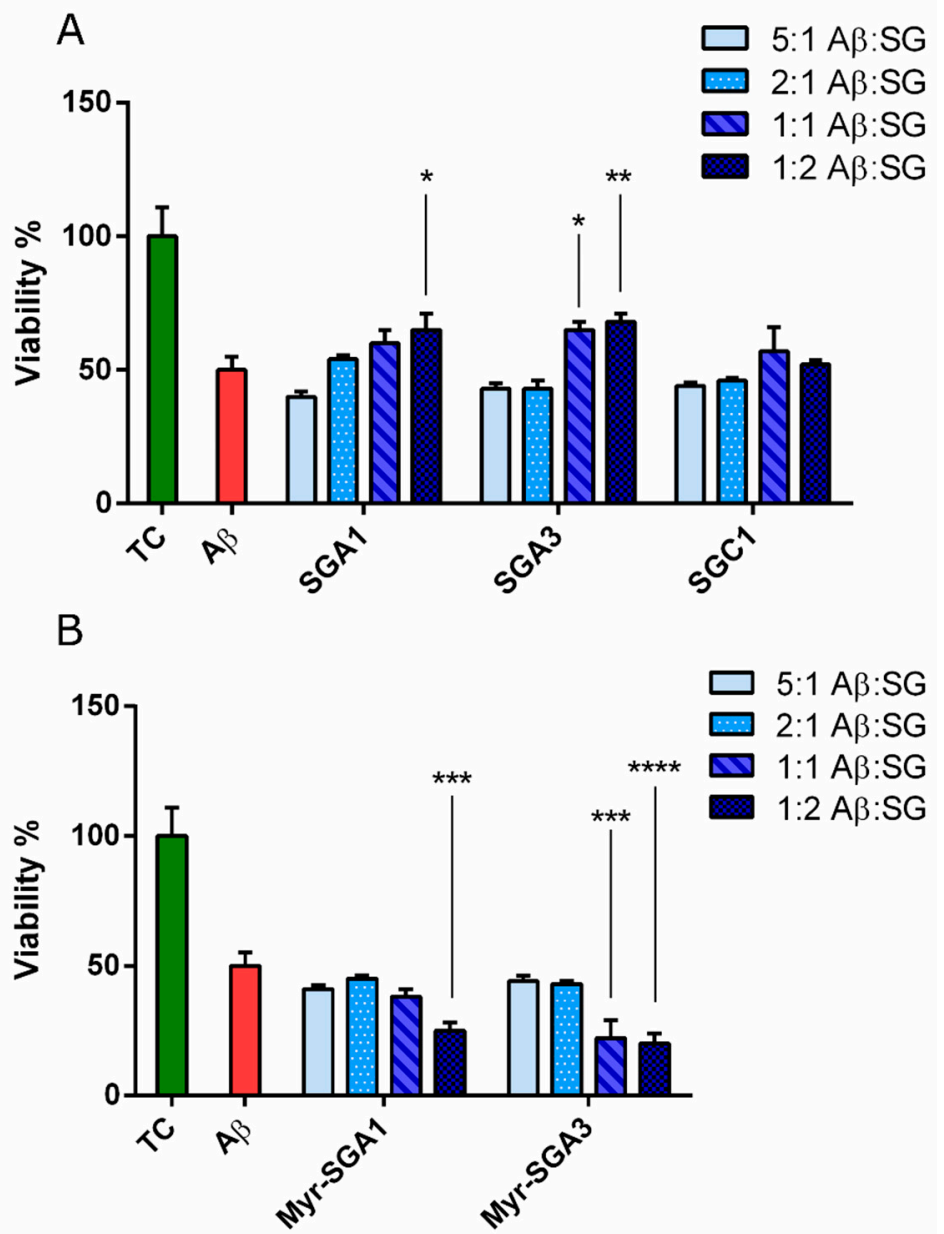

Figure 7. Effect of SG Inhibitors on A $\beta(1-42)$ Toxicity. Mean (with SEM) of HT22 cell viability as measured by MTT assay and expressed as a percentage of untreated control. Cells were treated with $\mathrm{A} \beta(n=6)$ or $\mathrm{A} \beta$ with various ratios of SG inhibitor 5:1 and 2:1 and 1:1 and 1:2 $(n=3)$ of $\mathrm{A} \beta / \mathrm{SG}$, for $24 \mathrm{~h}$. (A) Standard inhibitors and (B) Myristoylated SG inhibitors (bottom). Significance was assessed by one-way ANOVA $(\alpha=0.05)$ performed with Dunnett's multiple comparison to A $\beta$-treated group: ${ }^{*} p<0.05,{ }^{* *} p<0.01,{ }^{* * *} p<0.005$, and ${ }^{* * * *} p<0.001$.

AFM was used to confirm the structure of $5 \mu \mathrm{M} A \beta(1-42)$ and $5 \mu \mathrm{M} \mathrm{A} \beta(1-42)$ with SG inhibitor prepared in DMEM/F12 media similar to our previous report using the Stine protocol $[43,44]$. The $5 \mu \mathrm{M} \mathrm{A} \beta(1-42)$ and $5 \mu \mathrm{M} \mathrm{A} \beta(1-42)$ with SG inhibitor solutions prepared in DMEM/F12 media were incubated for 30-60 min on freshly cleaved mica 
followed by washing and drying. Representative images of oligomers, approximately 2 to $8 \mathrm{~nm}$, were produced and no fibrils were detected for any of the control or SG inhibitor $\mathrm{A} \beta(1-42)$ solutions (Figure 8). Moreover, incubation at $5 \mu \mathrm{M} \mathrm{A} \beta(1-42)$, compared to $100 \mu \mathrm{M}$ in the unmodified Stine protocol, should slow aggregation rates favoring low molecular weight and intermediate oligomeric $A \beta(1-42)$, rather than fibrillar $A \beta(1-42)$. Heterogeneous background was observed due to other media components absorbing onto the mica, forming a thin film.
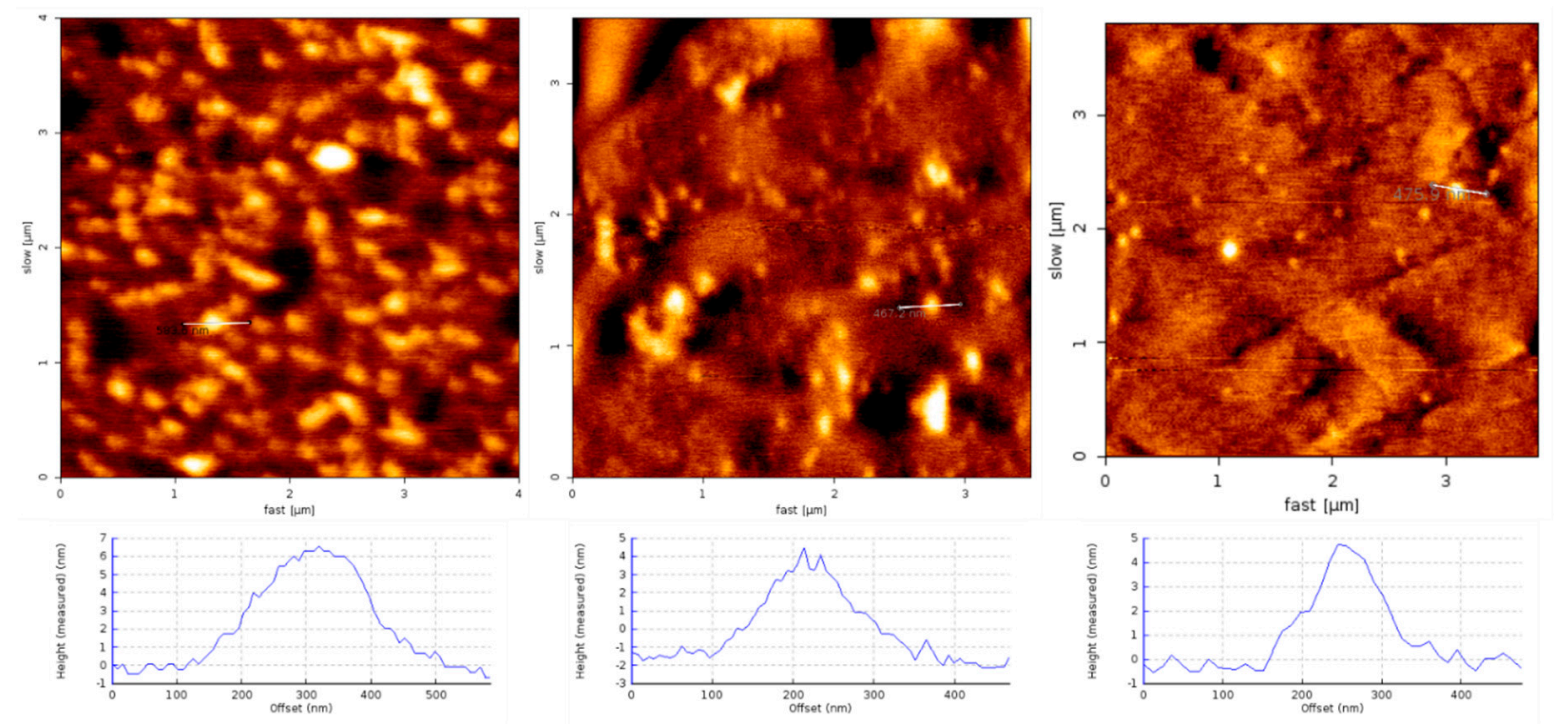

Figure 8. AFM images of $\mathrm{A} \beta(1-42)$ oligomers prepared at $5 \mu \mathrm{M}$ for $24 \mathrm{~h}$ at $4{ }^{\circ} \mathrm{C}$ in DMEM/F12 media deposited onto freshly cleaved mica, left panel A $\beta(1-42)$ control, middle panel 1:1 SGA1 to $A \beta(1-42)$ and right panel 2:1 SGA1 to A $\beta(1-42)$.

\section{Discussion}

\subsection{In vitro HT22 Cell Models for Testing Anti-Aß Aggregation Drugs}

The murine hippocampal-derived cell line HT22 was used in this study to assess cell viability to $A \beta(1-42)$ insult and ability of SG inhibitors to protect against this insult. HT22 cells are sensitive to glutamate excitotoxicity [45], express neuronal cholinergic markers [46]. These characteristics make HT22 cells suitable for evaluating the effects of $A \beta$ on cell viability, as cholinergic dysfunction and glutamate excitotoxicity are expected to be involved in A $\beta$ pathology and AD [47,48]. Most importantly, HT22 cells are sensitive to $\mathrm{A} \beta$ toxicity, as previous studies have examined the ability of neurotransmitters or hormones to bolster cell viability after $A \beta$ exposure [42,49]. These treatments will likely increase cell proliferation and metabolic activity through receptor signaling pathways, in addition to any effects of these small molecules on aggregation-dependent toxicity. For instance, treatment of nicotine at $10 \mu \mathrm{M}, 100 \mu \mathrm{M}$ and $500 \mu \mathrm{M}$ improved cell viability of HT22 cells treated with $5 \mu \mathrm{M} \mathrm{A} \beta(1-42)$ by approximately $10 \%$ to $20 \%$ [42]. This is comparable to the $15-18 \%$ improvement in cell viability we observed here with SGA inhibitors at $5-10 \mu \mathrm{M}$.

The trend towards decreased viability at low concentration was not statistically significant. In principle, if inhibitors slowed the fibrillization process, it may stabilize toxic $\mathrm{A} \beta(1-42)$ species. Considering previous ThT studies of SGA1, the $\mathrm{IC}_{50}$ inhibitory ratio was approximately 5:2 A $\beta / \mathrm{SG}$ ratio, which is between the lowest two concentrations we tested here. Thus, we expect that we are not at complete $A \beta$ inhibition at low concentration. In addition, based on AFM imaging studies at 1:1 A $\beta /$ SG ratio, we observed an increased oligomer/fibril ratio, suggesting that at higher $A \beta$, even at equimolar SG concentration, complete inhibition is not possible, though some protection is afforded.

This was the first report of the effects of A $\beta$ aggregation inhibitors in HT22 cells; the MTT cell viability results reported here verify the sensitivity of HT22 cells to $5 \mu \mathrm{M} \mathrm{A} \beta(1-42)$ oligomers. There is a complex equilibrium between the inhibitor and amyloid complexes 
(in this case: SG-SG, SG-A $\beta$ and $A \beta-A \beta$ ) in solution. Inhibitors are expected to be most effective when amyloid concentrations are low. However, to achieve an appreciable toxic effect over short-time scales, in vitro super-physiological concentrations of $A \beta$ must be used. Thus, caution in predicting the efficacy of amyloid inhibitors in vivo from in vitro assays is warranted. Inherent in the strategy of $A \beta$ aggregation is relying on physiological clearance mechanisms to remove monomeric species before they can aggregate, these would include BBB efflux and proteolytic breakdown and recycling. In acute treatment, in vitro assays do not accurately reflect this crucial portion of the mechanism, thus the assay is working against the intervention, which may explain the modest increase in neuroprotection that we observed. Overall, this style of acute assay is likely more suited for studying signaling and metabolic interventions rather than aggregation inhibitors, though this assay is still quite useful to rule out toxic compounds and identify potential candidates for further study.

\subsection{Myristic Acid to Improve BBB Delivery of Peptides}

Most central nervous system drugs are not able to permeate through the blood-brain barrier, especially drugs with a molecular weight greater than 500 Daltons [37]. As the SG inhibitors are greater than $500 \mathrm{Da}$, they will likely require a mechanism to facilitate transport across the BBB [37], thus the myristoylation of the SG inhibitors was proposed. This may improve passive diffusion by increasing hydrophobicity of the peptide, or via receptor-mediated translocation of fatty acid transporters [37]. The lipidation of proteins is a common post-translational modification that can localize the protein near the membrane and result in direct binding, insertion, and trafficking into the lipid bilayer [50,51]. Myristoylation of the SG inhibitors could localize the inhibitor in or near the membrane environment where $A \beta$ toxicity is initiated $[52,53]$. Interestingly, the myristoylation of the SG inhibitors resulted in direct cytotoxicity that was not observed in non-lipidated inhibitors. Saturated fatty acids (palmitic and stearic acids) have been shown to induce AD-like tau hyperphosphorylation, as well as trigger caspase-dependent and independent cell death mechanisms $[54,55]$. Though the peptide inhibitors are not strictly speaking free fatty acids, they may be regarded as fatty acid derivatives. The molecular mechanisms of lipotoxicity are expected to include ER, mitochondrial and oxidative stress [56]. Lipotoxicity has also been attributed to detergent-like and destabilizing effects on cellular membranes [56]. It is possible that myristoylated inhibitors are solubilizing or permeabilizing the outer cell and intracellular membranes. In addition, MD simulations show that Myr-SG inhibitors have a high homodimer stability, suggesting that they themselves may aggregate, leading to toxicity [30]. Finally, the enhanced cytotoxicity of the Myr-SG inhibitors may be due to their ability to insert themselves into the lipid bilayer and act as a seed for oligomerization, which is expected to be involved in the earliest stages of $A \beta$ toxicity. Our study demonstrates that myristoylation may not be a suitable strategy to increase the transport of peptide aggregation inhibitor drugs across the BBB.

\subsection{Comparing SG Inhibitors In Silico, Single Molecule Force Spectroscopy and Cell Viability Assays}

The inhibitors tested in this study were designed through computer-aided in silico drug design. Ligand-docking protocols and steered MD simulations were used to calculate a predicted affinity between the SG inhibitor and the target $A \beta(13-23)$, the self-recognition region (R) of the peptide HHQKLVFFAED [33]. In the computational studies, the selfrecognition region, $A \beta(13-23)$, is expected to be very flexible, with a hairpin turn between V18 and F19, forming an intramolecular $\beta$-sheet; this hairpin turn is stabilized by intramolecular interactions between the carboxylate group of E22 and the backbone $\mathrm{N}-\mathrm{H}$ bonds of V18, F19 and F20 [28,33,57]. Computational studies demonstrated that the SG inhibitors have a rigid backbone in comparison to $A \beta(13-23)$, due to the $\mathrm{N}$-methylated amine backbone which cannot form intramolecular hydrogen bonds and that the SG-R complex prevents the hairpin turn of $A \beta(13-23)$ increasing rigidity (Figure 2) $[21,28,30,31]$. Various substitutions of the SG inhibitor are made to maximize affinity for $A \beta 13-23$. N- 
terminal substitution of $\gamma$-diaminobutyric acid may improve interactions with D23 on A $\beta$; substitution of lysine in the KLVFF sequence with ornithine may improve electrostatic side chain interactions with E22 [33,57]. Other improvements to peptide inhibitors can be made by substituting various lipophilic aromatic residues, which may optimize hydrophobic interactions between the drug and $\mathrm{A} \beta$ target $[58,59]$.

Here, we demonstrate that SGA inhibitors, that are predicted to bind in an antiparallel fashion, have a significant protective effect against $A \beta(1-42)$ toxicity. In contrast, SGC1, predicted to bind in parallel fashion, had no effect on toxicity (Figure 3). In addition to the preferred binding orientation (parallel or anti-parallel), MD simulations have revealed that SG inhibitors can have preferred site and edge specificity to the top (RT) and bottom (RB) of $A \beta(13-23)$, and presumably full length $A \beta$; therefore, there are four possible binding orientations of the SG-A $\beta$ complex. To efficiently inhibit oligomerization, both top and bottom sites should be blocked by the inhibitor. In addition to the preferred binding configuration, inhibitors have some homodimer affinity (SG-SG complex) [21,30], which must be minimized to prevent competition for target engagement with $A \beta$ [31]. MD simulations and affinity calculations previously revealed that SGA1 is predicted to have preferential specificity for RT over RB, as indicated by the higher dissociation energy to RT and had relatively low homodimer dissociation energy [31]. SGA3 had high dissociation energies to both RT and RB, but also had a high homodimer stability compared to SGA1 [31]. This may explain the increase in protection that SGA3 afforded when compared to SGA1 at equimolar concentrations of $A \beta(1-42)$. When considering the edge and site specificity for SGC1, the computational study predicted that SGC1 had the most favorable predicted binding characteristics compared to SGA1 and SGA3, low homodimer stability and high $\mathrm{A} \beta$ binding. However, SGC1 did not have any effect on $\mathrm{A} \beta(1-42)$ toxicity, suggesting that a parallel binding orientation is much less protective than an anti-parallel orientation, despite more favorable effective $\Delta \mathrm{G}$. The SG inhibitors tested here are L-amino acid inhibitors that are more prone to degradation by endogenous proteases than the corresponding D-amino acid peptides, so we expect that the SGB and SGD compounds would be more effective. Moreover, the D-amino acid analogs appear to have more favorable binding characteristics [29].

In addition to the MD simulations, we previously conducted an SMFS biophysical study to test ability of SGA3, SGC1 and Myr-SGA1 to partially inhibit full length A $\beta(1-42)$ $\mathrm{A} \beta(1-42)$ dimerization demonstrating unique inhibiting properties of each inhibitor [30]. In these experiments, direct measurements of $A \beta$ dimerization were made, wherein the unbinding force of $A \beta$ was measured with and without SG inhibitor. In general, there was a bimodal distribution of rupture forces; this distribution could be attributed to two non-mutually exclusive mechanisms: first, that lower energy binding forces may correspond to hydrophobic interactions and higher energy rupture forces to the formation of hydrogen bonds; and second, to parallel and anti-parallel binding orientations. All inhibitors reduced the probability of binding, with no overall differences in the total number of events, however there were differences in the resulting force distributions, suggesting unique SG-A $\beta(1-42)$ complex formation. SGC1 increased the most probable unbinding force of the second mode of the distribution, this may be due to blocking parallel (lower energy) rather than antiparallel (higher energy) binding configurations, which could help to explain the limited effectiveness at protecting HT22 cells from A $\beta(1-42)$ toxicity [30]. SGA3 evenly reduced binding events across the histogram. In looking at Myr-SGA1 in SMFS experiments, we see a dramatic ability of the inhibitor to completely inhibit higher energy binding configurations but inability to prevent any of the lower energy binding configurations. This may indicate that Myr-SGA1 blocks hydrogen bonding (which could correspond to the higher energy state), but is unable to block lower energy hydrophobic interactions due to the myristic acid tail, thus the Myr-SG/A $\beta$ could be stabilizing the more cytotoxic forms of $A \beta$ oligomers. 


\section{Materials and Methods}

\subsection{Reagents and SG Inhibitors}

First, 1,1,1,3,3,3-hexafluoro-2-propanol (HFIP) (>99\%), DMEM/F12 media with LGlutamine, Fetal Bovine Serum (FBS), Penicillin/Streptamycin (Pen/Strep), Dimethylsulfoxide DMSO (>99\%), 3-(4,5-dimethylthiazol-2-yl)-2,5-diphenyltetrazolium bromide (MTT), Triton X-100. Amyloid- $\beta,>97 \%$ pure, HFIP purchased from rPeptide (Bogart, GA, USA). SG inhibitors ( $>95 \%$ pure) were synthesized by AnaSpec Inc. (Fremont, CA, USA); the sequences are shown in Table 2.

\subsection{HT22 Cells and MTT Assay}

The MTT assay was used to evaluate the viability of HT22 cells exposed to inhibitor or mixtures of inhibitor with full length A $\beta(1-42)$. HT22 cells were plated into 96-well cell culture plates at a cell density of 100,000 cells/mL in full growth media (DMEM/F12, with $10 \% \mathrm{FBS}, 1 \%$ Pen $/$ Strep) at $37^{\circ} \mathrm{C}, 5 \% \mathrm{CO} 2$, until $80 \%$ confluence (20-22 h). Full growth media was exchanged for treatment media (containing $A \beta$ or $A \beta$ with SG inhibitor). After treatment, cells are then returned to incubator for $24 \mathrm{~h}$. The media was then exchanged for phenol red-free DMEM/F12 containing $0.5 \mathrm{mg} / \mathrm{mL}$ MTT. Cells were returned to the incubator to metabolize the MTT for $3.5 \mathrm{~h}$, after which, cells were solubilized in isopropanol, with $10 \%$ Triton X-100 and $0.1 \mathrm{M} \mathrm{HCl}$. After solubilization, absorbance from the 96-well plates was read in Molecular Dynamics ${ }^{\mathrm{TM}}$ plate reader at $570 \mathrm{~nm}$ and $690 \mathrm{~nm}$. The signal at $690 \mathrm{~nm}$ and media control was subtracted from the $570 \mathrm{~nm}$ reading prior to analysis. HT22 cells were a generous gift from Dr. Robert Cumming, PhD, University of Western Ontario.

\section{3. $A \beta$ and $A \beta-S G$ Inhibitor Treatment Preparation and AFM Characterization}

$A \beta(1-42)$ oligomers were prepared following protocols adapted from Stine et al. [44]. Briefly, $A \beta(1-42)$ was dissolved in HFIP to $1 \mathrm{mg} / \mathrm{mL}$ solution and aliquoted into microcentrifuge tubes, and allowed to evaporate under desiccant for $24 \mathrm{~h}$, leaving behind a thin film of $A \beta(1-42)$ monomers, which was stored at $2-0{ }^{\circ} \mathrm{C}$ under desiccant. Immediately prior to use, $\mathrm{A} \beta(1-42)$ monomers were suspended in dimethyl sulfoxide (DMSO) at a concentration of $5 \mathrm{mM}$, vortexed for $30 \mathrm{~s}$, pulse centrifuged for $30 \mathrm{~s}$ and then sonicated for $10 \mathrm{~min}$ at room temperature. The $5 \mathrm{mM} \mathrm{A} \beta(1-42)$ monomer solution prepared in DMSO was then diluted to $100 \mu \mathrm{M}$ in cold DMEM/F12 media, then further diluted to $5 \mu \mathrm{M}$ in fresh DMEM/F12 or DMEM/F12 containing SG inhibitor at various concentrations corresponding to a final ratio of 5:1, 2:1, 1:1 and 1:2 A $\beta$ to SG. Solutions of $5 \mu \mathrm{M} \mathrm{A} \beta(1-42)$ (as control), or $5 \mu \mathrm{M}$ $\mathrm{A} \beta(1-42)$ with SG inhibitor were incubated at $4^{\circ} \mathrm{C}$ for $24 \mathrm{~h}$ under conditions favorable to produce intermediate oligomeric and smaller $A \beta(1-42)$ species.

$A \beta(1-42)$ oligomer species with and without SG inhibitor were confirmed by AFM imaging. Briefly, the $5 \mu \mathrm{M} \mathrm{A} \beta(1-42)$ and $5 \mu \mathrm{M} \mathrm{A} \beta(1-42)$ with SG inhibitor solutions (various ratios) in DMEM/F12 media were incubated for 30-60 min on freshly cleaved mica, followed by three washes with ultrapure water (MilliQ). Mica slides were dried using nitrogen and imaged with NCST soft tapping mode cantilevers (Nanoworld, Neuchâtel, Switzerland) using intermittent contact mode on the JPK Nanowizard 2 (JPK, Berlin, Germany).

\subsection{Statistical Analysis}

Inhibitor toxicity to HT22 cells was assessed by treating cells with inhibitor (SGA1, Myr-SGA1, SGA3, Myr-SGA3 or SGC1) at concentrations of 2.5, 5.0 and $10.0 \mu \mathrm{M}$ for $24 \mathrm{~h}$ in triplicates, for $n=4$ repeats. One-way ANOVA with Dunnett's multiple comparisons test was performed to establish significance between inhibitor groups and vehicle-treated control, threshold for significance: $\alpha=0.05$. To assess SG inhibitor neuroprotection against $A \beta(1-42)$ oligomers, $A \beta(1-42)$ alone or $A \beta(1-42)$ mixed with each inhibitor at the ratios described above were applied to cells in quadruplicates for $n=3$ repeats. One-way ANOVA with Dunnett's multiple comparisons was performed to establish significance between $\mathrm{A} \beta$-SG inhibitor mixture and A $\beta$-treated control; threshold for significance: $\alpha=0.05$. 


\section{Conclusions}

We showed that several SG inhibitors demonstrated promising ability to protect HT22 cells from $A \beta(1-42)$ toxicity. Based on previous studies, the mechanisms involve binding to $A \beta(1-42)$ and preventing its misfolding, and more specifically that the anti-parallel (SGA) binding inhibitors are more likely to protect cells than those that bind in a parallel (SGC) orientation. We also showed that myristic acid modified SG-peptides are neurotoxic themselves and may not be suitable as amyloid prevention drug candidates. We suggest that this in vitro study justifies further screening of a larger set of SG inhibitors in more physiologically relevant in vivo models. As this is the first such in vitro test of anti-A $\beta$ aggregation compounds in HT22 cells, it sets a benchmark for future in vitro studies of amyloid aggregation inhibitors in this cell line. Testing of SGB inhibitors, the D-enantiomers of the anti-parallel binding SG inhibitors is the next step in the drug development pipeline.

Author Contributions: Conceptualization, Z.L., M.B. and A.R.; methodology, J.L., M.R. and M.B.; writing—original draft preparation, M.R.; writing—review and editing, M.R., J.L., B.M., Z.L., M.B. and A.R.; visualization, M.R. and B.M.; supervision, Z.L. and M.B.; funding acquisition, Z.L., M.B. and A.R. All authors have read and agreed to the published version of the manuscript.

Funding: This research was funded by the Natural Sciences and Engineering Research Council of Canada (NSERC) grants awarded to Zoya Leonenko, Arvi Rauk and Michael Beazely; support for Jennifer Lou was provided by NSERC - Undergraduate Student Research Award (USRA) award; further support was provided by seed funding from the Chronic Disease Prevention Institute (CDPI) and Network on Aging Research (NAR) at the University of Waterloo awarded to Zoya Leonenko and Michael Beazely.

Institutional Review Board Statement: Not applicable.

Informed Consent Statement: Not applicable.

Data Availability Statement: The data presented in this study are available in the article.

Acknowledgments: We thank Nyasha Gondora and Nawaz Ahmed for help with experimental design and cell culture training of Morgan Robinson and Jennifer Lou.

Conflicts of Interest: The authors declare no conflict of interest.

\begin{tabular}{ll}
\multicolumn{2}{l}{ Abbreviations } \\
A $\beta$ & amyloid- $\beta$ \\
AD & Alzheimer's disease \\
ANOVA & analysis of variance \\
BBB & blood-brain barrier \\
CNS & central nervous system \\
DMSO & dimethylsulfoxide \\
HFIP & hexafluoroisopropanol \\
MD & molecular dynamics \\
MOE & Molecular Environment \\
MTT & 3-(4,5-Dimethylthiazol-2-yl)-2,5-Diphenyltetrazolium Bromide \\
mAb & monoclonal antibody \\
SMFS & single-molecule force spectroscopy
\end{tabular}

\section{References}

1. Thinakaran, G.; Koo, E.H. Amyloid precursor protein trafficking, processing, and function. J. Biol. Chem. 2008, 283, 29615-29619. [CrossRef] [PubMed]

2. Hardy, J.A.; Higgins, G.A. Alzheimer's disease: The amyloid cascade hypothesis. Science 1992, 256, 184-185. [CrossRef] [PubMed]

3. Hardy, J.; Selkoe, D.J. The amyloid hypothesis of Alzheimer's disease: Progress and problems on the road to therapeutics. Science 2002, 297, 353-356. [CrossRef] [PubMed]

4. Ono, K.; Condron, M.M.; Teplow, D.B. Structure-neurotoxicity relationships of amyloid $\beta$-protein oligomers. Proc. Natl. Acad. Sci. USA 2009, 106, 14745-14750. [CrossRef] 
5. Cecchi, C.; Stefani, M. The amyloid-cell membrane system. The interplay between the biophysical features of oligomers/fibrils and cell membrane defines amyloid toxicity. Biophys. Chem. 2013, 182, 30-43. [CrossRef]

6. Williams, T.L.; Johnson, B.R.G.; Urbanc, B.; Jenkins, A.T.A.; Connell, S.D.A.; Serpell, L.C. A $\beta 42$ oligomers, but not fibrils, simultaneously bind to and cause damage to ganglioside-containing lipid membranes. Biochem. J. 2011, 439, 67-77. [CrossRef]

7. Karran, E.; Mercken, M.; De Strooper, B. The amyloid cascade hypothesis for Alzheimer's disease: An appraisal for the development of therapeutics. Nat. Rev. Drug Discov. 2011, 10, 698-712. [CrossRef]

8. Laske, C. Phase 3 Trials of Solanezumab and Bapineuzumab for Alzheimer's Disease. N. Engl. J. Med. 2014, 370, 1459-1460. [CrossRef]

9. Doody, R.S.; Thomas, R.G.; Farlow, M.; Iwatsubo, T.; Vellas, B.; Joffe, S.; Kieburtz, K.; Raman, R.; Sun, X.; Aisen, P.S.; et al. Phase 3 Trials of Solanezumab for Mild-to-Moderate Alzheimer's Disease. N. Engl. J. Med. 2014, 370, 311-321. [CrossRef]

10. Panza, F.; Solfrizzi, V.; Imbimbo, B.P.; Giannini, M.; Santamato, A.; Seripa, D.; Logroscino, G. Efficacy and safety studies of gantenerumab in patients with Alzheimer's disease. Expert Rev. Neurother. 2014, 14, 973-986. [CrossRef]

11. Siemers, E.R.; Sundell, K.L.; Carlson, C.; Case, M.; Sethuraman, G.; Liu-Seifert, H.; Dowsett, S.A.; Pontecorvo, M.J.; Dean, R.A.; DeMattos, R. Phase 3 solanezumab trials: Secondary outcomes in mild Alzheimer's disease patients. Alzheimer's Dement. 2016, 12, 110-120. [CrossRef] [PubMed]

12. Liu-Seifert, H.; Siemers, E.; Holdridge, K.C.; Andersen, S.W.; Lipkovich, I.; Carlson, C.; Sethuraman, G.; Hoog, S.; Hayduk, R.; Doody, R.; et al. Delayed-start analysis: Mild Alzheimer's disease patients in solanezumab trials, 3.5 years. Alzheimer's Dement. Transl. Res. Clin. Interv. 2015, 1, 111-121. [CrossRef] [PubMed]

13. Sevigny, J.; Chiao, P.; Bussière, T.; Weinreb, P.H.; Williams, L.; Maier, M.; Dunstan, R.; Salloway, S.; Chen, T.; Ling, Y.; et al. The antibody aducanumab reduces $A \beta$ plaques in Alzheimer's disease. Nature 2016, 537, 50-56. [CrossRef] [PubMed]

14. Ghanta, J.; Shen, C.L.; Kiessling, L.L.; Murphy, R.M. A strategy for designing inhibitors of $\beta$-amyloid toxicity. J. Biol. Chem. 1996, 271, 29525-29528. [CrossRef] [PubMed]

15. Tjernberg, L.O.; Näslundt, J.; Lindqvist, F.; Johansson, J.; Karlström, A.R.; Thyberg, J.; Tereniust, L.; Nordstedt, C. Arrest of $\beta$-amyloid fibril formation by a pentapeptide ligand. J. Biol. Chem. 1996, 271, 8545-8548. [CrossRef]

16. Tjernberg, L.O.; Lilliehöök, C.; Callaway, D.J.E.; Näslund, J.; Hahne, S.; Thyberg, J.; Terenius, L.; Nordstedt, C. Controlling amyloid $\beta$-peptide fibril formation with protease-stable ligand. J. Biol. Chem. 1997, 272, 12601-12605. [CrossRef]

17. Austen, B.M.; Paleologou, K.E.; Ali, S.A.E.; Qureshi, M.M.; Allsop, D.; El-Agnaf, O.M.A. Designing peptide inhibitors for oligomerization and toxicity of Alzheimer's $\beta$-amyloid peptide. Biochemistry 2008, 47, 1984-1992. [CrossRef]

18. Lowe, T.L.; Strzelec, A.; Kiessling, L.L.; Murphy, R.M. Structure-Function relationships for inhibitors of $\beta$-Amyloid toxicity containing the recognition sequence KLVFF. Biochemistry 2001, 40, 7882-7889. [CrossRef]

19. Grillo-Bosch, D.; Carulla, N.; Cruz, M.; Sánchez, L.; Pujol-Pina, R.; Madurga, S.; Rabanal, F.; Giralt, E. Retro-enantio N-methylated peptides as $\beta$-amyloid aggregation inhibitors. ChemMedChem 2009, 4, 1488-1494. [CrossRef]

20. Soto, C.; Kindy, M.S.; Baumann, M.; Frangione, B. Inhibition of Alzheimer's Amyloidosis by Peptides That Prevent $\beta$-Sheet Conformation. Biochem. Biophys. Res. Commun. 1996, 226, 672-680. [CrossRef]

21. Hane, F.T.; Lee, B.Y.; Petoyan, A.; Rauk, A.; Leonenko, Z. Testing synthetic amyloid- $\beta$ aggregation inhibitor using single molecule atomic force spectroscopy. Biosens. Bioelectron. 2014, 54, 492-498. [CrossRef] [PubMed]

22. Soto, C.; Sigurdsson, E.M. $\beta$-sheet breaker peptides inhibit fibrillogenesis in a rat brain model of amyloidosis: Implications for Alzheimer's therapy. Nat. Med. 1998, 4, 623-626. [CrossRef] [PubMed]

23. Chacón, M.A.; Barría, M.I.; Soto, C.; Inestrosa, N.C. $\beta$-sheet breaker peptide prevents A $\beta$-induced spatial memory impairments with partial reduction of amyloid deposits. Mol. Psychiatry 2004, 9, 953-961. [CrossRef] [PubMed]

24. Parthsarathy, V.; McClean, P.L.; Hölscher, C.; Taylor, M.; Tinker, C.; Jones, G.; Kolosov, O.; Salvati, E.; Gregori, M.; Masserini, M.; et al. A Novel Retro-Inverso Peptide Inhibitor Reduces Amyloid Deposition, Oxidation and Inflammation and Stimulates Neurogenesis in the APPswe/PS1 $\triangle$ E9 Mouse Model of Alzheimer's Disease. PLoS ONE 2013, 8, e54769. [CrossRef]

25. Taylor, M.; Moore, S.; Mayes, J.; Parkin, E.; Beeg, M.; Canovi, M.; Gobbi, M.; Mann, D.M.A.; Allsop, D. Development of a proteolytically stable retro-inverso peptide inhibitor of $\beta$-amyloid oligomerization as a potential novel treatment for Alzheimers Disease. Biochemistry 2010, 49, 3261-3272. [CrossRef]

26. Pallitto, M.M.; Ghanta, J.; Heinzelman, P.; Kiessling, L.L.; Murphy, R.M. Recognition sequence design for peptidyl modulators of $\beta$-amyloid aggregation and toxicity. Biochemistry 1999, 38, 3570-3578. [CrossRef]

27. Hane, F.T.; Robinson, M.; Lee, B.Y.; Bai, O.; Leonenko, Z.; Albert, M.S. Recent Progress in Alzheimer's Disease Research, Part 3: Diagnosis and Treatment. J. Alzheimer's Dis. 2017, 57, 645-665. [CrossRef]

28. Opare, S.K.A.; Petoyan, A.; Mehrazma, B.; Rauk, A. Molecular dynamics study of the monomers and dimers of N-AcA $\beta$ (13-23) NH2: On the effect of $\mathrm{pH}$ on the aggregation of the amyloid beta peptide of Alzheimer's disease. Can. J. Chem. 2015, 94, 273-281. [CrossRef]

29. Mehrazma, B.; Opare, S.; Petoyan, A.; Rauk, A. D-amino acid pseudopeptides as potential amyloid-beta aggregation inhibitors. Molecules 2018, 23, 2387. [CrossRef]

30. Robinson, M.; Mehrazma, B.; Opare, S.K.A.; Petoyan, A.; Lou, J.; Hane, F.T.; Rauk, A.; Leonenko, Z. Pseudo-peptide Amyloid- $\beta$ Blocking Inhibitors: Molecular Dynamics and Single Molecule Force Spectroscopy Study. BBA Proteins Proteom. 2017, 1865, 1707-1718. 
31. Mehrazma, B.; Petoyan, A.; Opare, S.K.A.; Rauk, A. Interaction of the N-AcA $\beta$ (13-23) NH 2 segment of the beta amyloid peptide with beta-sheet-blocking peptides: Site and edge specificity. Can. J. Chem. 2016, 10, 1-10. [CrossRef]

32. Gordon, D.J.; Tappe, R.; Meredith, S.C. Design and characterization of a membrane permeable N-methyl amino acid-containing peptide that inhibits Abeta1-40 fibrillogenesis. J. Pept. Res. 2002, 60, 37-55. [CrossRef] [PubMed]

33. Roy, S. Designing Novel Peptidic Inhibitors of Beta Amyloid Oligomerization. Ph.D. Thesis, University of Calgary, Calgary, AB, Canada, 2010.

34. Cruz, M.; Tusell, J.M.; Grillo-Bosch, D.; Albericio, F.; Serratosa, J.; Rabanal, F.; Giralt, E. Inhibition of $\beta$-amyloid toxicity by short peptides containing N-methyl amino acids. J. Pept. Res. 2004, 63, 324-328. [CrossRef] [PubMed]

35. Poduslo, J.F.; Curran, G.L.; Kumar, A.; Frangione, B.; Soto, C. $\beta$-Sheet breaker peptide inhibitor of Alzheimer's amyloidogenesis with increased blood-brain barrier permeability and resistance to proteolytic degradation in plasma. J. Neurobiol. 1999, 39, 371-382. [CrossRef]

36. Kokkoni, N.; Stott, K.; Amijee, H.; Mason, J.M.; Doig, A.J. N-methylated peptide inhibitors of $\beta$-amyloid aggregation and toxicity. Optimization of the inhibitor structure. Biochemistry 2006, 45, 9906-9918. [CrossRef]

37. Robinson, M.; Yasie Lee, B.; Leonenko, Z. Drugs and drug delivery systems targeting amyloid- $\beta$ in Alzheimer's disease. AIMS Mol. Sci. 2015, 2, 332-358. [CrossRef]

38. Buser, C.A.; Sigal, C.T.; Resh, M.D.; McLaughlin, S. Membrane binding of myristylated peptides corresponding to the NH2 terminus of Src. Biochemistry 1994, 33, 13093-13101. [CrossRef]

39. Nelson, A.R.; Borland, L.; Allbritton, N.L.; Sims, C.E. Myristoyl-based transport of peptides into living cells. Biochemistry 2007, 46, 14771-14781. [CrossRef]

40. Hane, F.T.; Attwood, S.J.; Leonenko, Z. Comparison of three competing dynamic force spectroscopy models to study binding forces of amyloid- $\beta$ (1-42). Soft Matter 2014, 10, 1924-1930. [CrossRef]

41. Hane, F.; Leonenko, Z. Effect of Metals on Kinetic Pathways of Amyloid- $\beta$ Aggregation. Biomolecules 2014, 4, 101-116. [CrossRef]

42. Wu, M.; Jia, J.; Lei, C.; Ji, L.; Chen, X.; Sang, H.; Xiong, L. Cannabinoid Receptor CB1 Is Involved in Nicotine-Induced Protection Against A $\beta$ 1-42 Neurotoxicity in HT22 Cells. J. Mol. Neurosci. 2014, 55, 778-787. [CrossRef] [PubMed]

43. Liu, H.; Saffi, G.T.; Vasefi, M.S.; Choi, Y.; Kruk, J.S.; Ahmed, N.; Gondora, N.; Mielke, J.; Leonenko, Z.; Beazely, M.A. Amyloid- $\beta$ Inhibits PDGF $\beta$ Receptor Activation and Prevents PDGF-BB-induced Neuroprotection. Curr. Alzheimer Res. 2018, 15, 618-627. [CrossRef]

44. Stine, W.B.; Jungbauer, L.; Yu, C.; LaDu, M.J. Preparing synthetic A $\beta$ in different aggregation states. Methods Mol. Biol. 2011, 670, 13-32. [CrossRef] [PubMed]

45. Davis, J.B.; Maher, P. Protein kinase C activation inhibits glutamate-induced cytotoxicity in a neuronal cell line. Brain Res. 1994, 652, 169-173. [CrossRef]

46. Liu, J.; Li, L.; Suo, W.Z. HT22 hippocampal neuronal cell line possesses functional cholinergic properties. Life Sci. 2009, 84, 267-271. [CrossRef]

47. Hynd, M.R.; Scott, H.L.; Dodd, P.R. Glutamate-mediated excitotoxicity and neurodegeneration in Alzheimer's disease. Neurochem. Int. 2004, 45, 583-595. [CrossRef]

48. Snyder, E.M.; Nong, Y.; Almeida, C.G.; Paul, S.; Moran, T.; Choi, E.Y.; Nairn, A.C.; Salter, M.W.; Lombroso, P.J.; Gouras, G.K.; et al. Regulation of NMDA receptor trafficking by amyloid- $\beta$. Nat. Neurosci. 2005, 8, 1051-1058. [CrossRef]

49. Gursoy, E.; Cardounel, A.; Kalimi, M. Pregnenolone Protects Mouse Hippocampal (HT-22) Cells against Glutamate and Amyloid Beta Protein Toxicity. Neurochem. Res. 2001, 26, 15-21. [CrossRef]

50. Charron, G. Protein Lipidation and Lipid Trafficking. Acc. Chem. Res. 2011, 44, 699-708. [CrossRef]

51. Aicart-Ramos, C.; Valero, R.A.; Rodriguez-Crespo, I. Protein palmitoylation and subcellular trafficking. Biochim. Biophys. Acta Biomembr. 2011, 1808, 2981-2994. [CrossRef]

52. Sepulveda, F.J.; Parodi, J.; Peoples, R.W.; Opazo, C.; Aguayo, L.G. Synaptotoxicity of Alzheimer beta amyloid can be explained by its membrane perforating property. PLoS ONE 2010, 5, e11820. [CrossRef] [PubMed]

53. Drolle, E.; Negoda, A.; Hammond, K.; Pavlov, E.; Leonenko, Z. Changes in lipid membranes may trigger amyloid toxicity in Alzheimer's disease. PLoS ONE 2017, 12, e0182194. [CrossRef] [PubMed]

54. Ulloth, J.E.; Casiano, C.A.; De Leon, M. Palmitic and stearic fatty acids induce caspase-dependent and-independent cell death in nerve growth factor differentiated PC12 cells. J. Neurochem. 2003, 84, 655-668. [CrossRef] [PubMed]

55. Patil, S.; Chan, C. Palmitic and stearic fatty acids induce Alzheimer-like hyperphosphorylation of tau in primary rat cortical neurons. Neurosci. Lett. 2005, 384, 288-293. [CrossRef]

56. Borradaile, N.M.; Han, X.; Harp, J.D.; Gale, S.E.; Ory, D.S.; Schaffer, J.E. Disruption of endoplasmic reticulum structure and integrity in lipotoxic cell death. J. Lipid Res. 2006, 47, 2726-2737. [CrossRef] [PubMed]

57. Mothana, B.; Roy, S.; Rauk, A. Molecular dynamics study of the interaction of A $\beta$ (13-23) with $\beta$-sheet inhibitors. Arkivoc 2009, 116-134. [CrossRef]

58. Porat, Y.; Mazor, Y.; Efrat, S.; Gazit, E. Inhibition of islet amyloid polypeptide fibril formation: A potential role for heteroaromatic interactions. Biochemistry 2004, 43, 14454-14462. [CrossRef] [PubMed]

59. Cohen, T.; Frydman-Marom, A.; Rechter, M.; Gazit, E. Inhibition of amyloid fibril formation and cytotoxicity by hydroxyindole derivatives. Biochemistry 2006, 45, 4727-4735. [CrossRef] 